ments (gravity operated), the nature of erosion (transport in channels), the form of deposited waste and the control by base-level. In his theoretical treatment of land forms he uses the method of the differential calculus, considering for each small fragment of the crust its net movement, the resultant of crustal displacement on the one hand and denudation and deposition on the other. In this way several sequences of developing forms, waxing, waning, etc., are arrived at. This discussion of principle leads to an analysis of various forms of slope, breaks of slope, linking of slopes, and associations of forms, each explained by diagrams and illustrated by photographs.

At every stage he is very careful to define his terms, and his terms constitute a whole new vocabulary. The coining of English equivalents for such words as "auf bereitung" or " haldenhang " or the equating of them with existing geomorphological terms has been the most difficult part of the translation. There is a glossary of about 150 terms.

The son of a famous geographer (Albrecht Penck), Walther had made great contributions to geology and geomorphology before he died at the early age of 35 with his great work unfinished. It was published posthumously by his father. By a tragic coincidence one of his translator; (Miss Boswell) also died (at Beni Abbès while attending the Nineteenth International Congress of Geology) before this present work saw publication. English-speaking geologists and geomorphologists owe to her and her collaborator, Dr. Hella Czech, a great debt, not only for making the important and violently controversial views of Walther Penck available, but also for providing a biography, a bibliography, and about 50 pages of explanatory notes by which one may know the man as well as his work.

The translators have wisely adhered closely to the original German text although it is wordy and often obscure, but Miss Boswell has provided a short cut to the conclusions by means of a chapter-by-chapter summary of about 60 pages.

A. A. M.

\title{
CORRESPONDENCE
}

\section{A TEMPORARY SECTION IN THE MALVERNS}

SIR,-During the excavation which preceded the laying of an electric cable across the southern end of Hereford Beacon, the rocks exposed in a short section of the cable trench were observed by one of us (R. E. B.) during a chance visit. The locality, shown on the accompanying sketch-map, is at the northern end of Groom's "Silurian Pass", between Swinyard Hill and Hangmans Hill. Near the junction of the paths a pit was excavated and had been lined before the time of the visit; but the spoil from it consisted of purple Mayhill Sandstone (Upper Llandovery) at the south end of the pit, and an argillaceous limestone at the north end. In an accessible part of the trench, which followed the track on the east side of Swinyard Hill, limestone was seen faulted against shale just north of the pit. The fault trended northwest and dipped steeply, but the trench was too shallow to allow of proper estimation of the dip. The limestone formed the south-west wall of the fault, and was broken by slickensided surfaces, one group of which were striking approximately north-east and dipped steeply south-east. The slickensides indicated a mainly vertical movement. Scanty fossils (corals and 
brachiopods) from the limestone would agree with a Wenlock age, but would not exclude Woolhope.

Known exposures of limestone lie in the old track (point $A$ on sketchmap) east of the trench, and are now partly covered with spoil. About 90 yards to the north, spoil from an excavation for a pylon contained much limestone. Limestone is also exposed at B on the map. The evidence therefore suggests that a belt of limestone is present in the Silurian outcrop here, and a suggested boundary for it is shown by a dotted line. The exposure marked $\mathrm{C}$ on the map is mass of Pre-Cambrian, possibly forming a fault-slice within the Silurian.

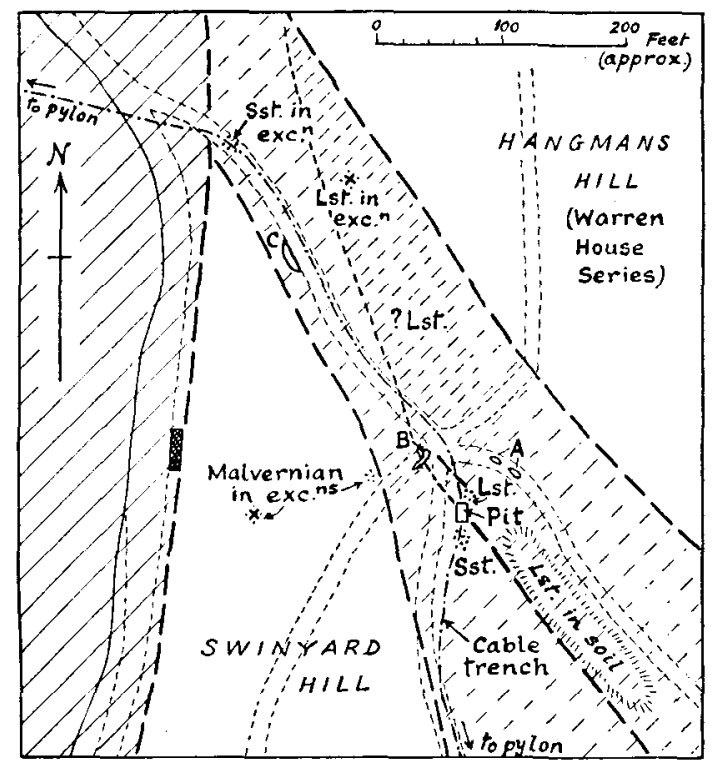

Sketch-map of the Silurian area (northern end) between Swinyard Hill and Hangmans Hill, to show localities referred to in text. Diagonal shading, Silurian; Pre-Cambrian unshaded. Heavy broken lines are faults. (Lst. $=$ limestone; Sst. $=$ sandstone; excn. = excavation.)

At the time of the visit (October, 1952) most of the trench had been filled in, and we should be interested to hear of observations made by anyone who happened to see the locality before that date, when access to the excavation was better.

The new evidence may necessitate some adjustments of earlier mapped lines in what is clearly a complex fracture zone. The boundaries shown on the sketch are a tentative interpretation of the observations available.

F. G. H. Blyth and R. E. Blackith.

\section{Geology Department, \\ IMPERIAL COLleGE, LONDON. \\ 1st October, 1953.}

